\title{
The Influence of Social Media on Political Consciousness: Presidential Election of The Gambia 2016
}

\author{
Yaya B. Baldeh \\ Graduate School of Social Sciences, Ankara University, Department of Journalism
}

\begin{abstract}
The increasing role the media continue to play in the overall societal development arena is immense. In recent times, not only the mainstream media is helping in the consolidation and upholding role in amplifying vibrant democracy, but even the newest evolving new media is doing a far greater job in enlightening the people. This, of course, is incredibly attributed to new sophistication media tools. These networking sites include Facebook, Twitter, WhatsApp, YouTube, the list goes on. These platforms are adding further spice and also influencing crucial decisions in the area of politics, electioneering as well as societal change phases. The power of social media, particularly the visibility aspect is aiding voters to make crucial decisions when it comes to voting and assessing relevant information relating to policy. Countless people rely on the new media in search of daily news feeds, following online debates on domestic politics amongst other useful issues. Perhaps, this is needed now more than ever before in the current political climate and increasing political consciousness across Sub-Saharan countries like The Gambia. As the study of a single country, The Gambia, the findings go further to ascertain and analyse truly ways in which social media have contributed to democratic transition and the gains it might have ushered in for the country's political scene.This research undertaking evaluates the ever increasing significant role played by social media in The Gambia's 2016 Presidential Election. It further examines the influence of social media in relation to the political consciousness on the part of Gambian voters in the December 1, 2016 Presidential polls. If anything, it helped bring an end to the 22-year dictatorial regime overnight in the West African nation.Further, a quantitative method was applied in the research to establish the findings. The study methodology employed to analyse the collected data using Statistical Package for Social Sciences (SPSS). This was done to ascertain whether social media had any meaningful impact on the mind-sets of ordinary citizens in the passage of crucial decision in the election. Again, as a result of increasing trend of social media usage for information consumption in the public space, the curiosity of this study interrogates this question, can it translate into massive voter turnout in elections as a prime case of The Gambia?
\end{abstract}

Keywords: Social Media; Election; Political Consciousness; Social Movement; The Gambia

DOI: $10.7176 / \mathrm{NMMC} / 84-04$

Publication date:October $31^{\text {st }} 2019$

\section{Introduction}

Globally, social media constitute an instrumental part in human life in recent years. It continues to generate intense attention, especially in our political interaction cycle. Political players use it across the globe to amass support from potential voters. Mostly, some significant indications have proven that remarkable gains registered by social media in bringing people together is high. In the political space, social media platforms have been credited for playing incredible role in elections, notably in the developed World.

Owing to the aforementioned scenarios, the world we are living is now regarded as a "global village". The influence of social media is gaining momentum by the day to an extent that certain nascent societies are playing catch up, with its wind of change allowing ordinary citizens the space to express their political thoughts and opinions.

Some scholarly discourse continues to generate intense debate on the increasing use of social media in the political spectrum. Besides elections campaign, the evolutions in social media are helping to injecting an unprecedented level of awareness on contemporary global politics. A case in point is the widely cited landmark changes it bears as exemplified in 2008 American Presidential Election to the so-called "Arab Spring" in 2011. Social media has virtually changed the political landscape and sparked a broad liberalisation of information faster than the mainstream media (Dutta and Bhat, 2017).

It ideally goes to state that when we carefully look at the political arena the amalgamation of multi-faceted communication channels grows bigger by the day. Interestingly, this becomes more participatory as networked populations also appear wider in varieties. Such facilitating media like Facebook, Twitter, Youtube and WhatsApp are widely believed to possess far greater indispensable communicative means ever than it used to be. Social media has been described as one of the fastest and is growing exponentially in shaping the communicative mood of our time.

As been articulated by Philip Howard, new information and communication technologies (ICTs), such as the Internet and mobile phones, have had clear roles both in starting new democratic processes in some countries and in entrenching them (leaders) in others (Howard, 2011:3). The relevance accompanied by social media sites 
in enhancing numerous helpful things are detectable. Ranging from communicating personal matters; surfing for daily news feed; talking politics; partaking civics discourse. The list goes on for its advantages it brought for it users. In the Internet Age, tyrants will have to reckon with people's autonomous communication capacity (Castells, 2015: 67).

Owning to the increasing nature of changes being registered over the years more specifically in places like Indonesia, activists were able to meaningfully utilise the sophistication embedded in technology such as mobile phones to mobilise people that apparently gave them winning power to topple the former Indonesian president, Hajji Suharto in 1998.

Also, another most referenced cases are that of Egypt, Tunisia and Kazakhstan. Interestingly enough, in this cited countries opposition cohorts who one-time suffered bitterly state censorship simply took a new approach by innovatively embracing the online content of their messages to servers in another countries different from their home countries. This eventually works for them.

Further, the winds of political substitution witnessed in certain African countries notably, Egypt and Tunisia undoubtedly saw the fall of dictatorial regimes falling from grace to grass. Indeed, this is seen to be aided by the potency of revolts through social media.

With this, certain political analysts had the conviction that social media is likely to be the saviour of Africa's search for democracy. For example, during the "Arab Spring" (2011 uprising) per se, docile ordinary citizens would prefer to be glued to the internet to fetch out information deemed crucial to them. In reality, such information would hardly come by through their existing mainstream media outlets.

Although in participatory democracy the claim that the Internet is delivering this aspect is seen as an ideological illusion (Hand and Sandywell 2002: 204). Essentially, the rise of digital activism and social media as a tool for political campaigning has also added new dimensions to the transforming political scene of recent. Ideally, the proliferation of digital technologies and their impact on the ordinary person's lives can confirm the individualisation of politics that began in the 1990s (Almqvist, 2016: 2).

In this newest contemporary political communication phase according to Howard, citizens turn to the Internet as a source of news and information in times of political mayhem. Additionally, not only online social networking services are influential rather they also a fundamental infrastructure for social movements (Howard, 2011: 10).

Moreover, bearing in mind that the liberating power often been attributed to the Internet and social media as sometimes claimed, new sources of alternative information are speedily accelerating and becoming available to certain parts of the globe and by extension the African continent. We have over the years seen Kenya's elections fracas and how citizens were able to use new media platforms to access and share information. This, as argued by William Gumede that, new media platforms, especially where the old media (mainstream media) are firmly controlled by governments. It has the potential to open new ways to produce and distribute independent information to mass audience, normally accessed only by government media (Gumede, 2016).

Social Media power is being hailed to have engineered the toppling of the leaderships of certain societies. However, the exploratory journey toward political impact of digital media is yet difficult to assay. This is the curiosity aspect this research intends to uncover - whether this claim is applicable or not to Sub-Saharan African countries like The Gambia.

\subsection{The Gambia Socio-economic and Political Landscape}

The Gambia's socio-economic development outlook highly reflects its long-standing history of crippling misgovernance. Just as in many other fellow African countries, poverty stands out clear. Recently, the country's poverty scale is projected and ranked $175^{\text {th }}$ out of 188 countries in the United Nations Development Programme's 2015 Human Development index.

A country often hailed as amongst African sub-region's boiling pot of opportunity is relatively a classic example of a small economy that relies predominantly on tourism, agriculture, and remittances wired into the country. As a prime mover and strategic player, especially in the ocean of its nation's belt, The Gambia just stretches some $450 \mathrm{~km}$ along The Gambia River. It's about 11,295 square km, 50 per cent of which is arable land.

Geographically, The Gambia is surrounded on all sides- from its northern, southern and eastern sides by its neighbor, the Republic of Senegal except its west, wherein lies the Atlantic Coastline (ocean). With the view of its locations, the country harbours some wealth of land, making it globally a significant destination that mainly attracts tourists from both regional and international level. Additionally, the smallest West African nation is ideally a great viable hub for trade in Africa, especially with re-emergence of democracy and open space for business environment. This is in sharp contrast to its recent past as a country under self-imposed exile from the internal.

In respect of socio-economic realities, it is indicated that The Gambia's GDP growth rate stands at 4.3 per cent as of 2015. Also, 48.6 per cent of its citizens living below the income poverty line pegged at US\$1.25 per day (Gambia Bureau of Statistics Report 2013). The country is endowed with vast arable land with its active 
vigor in the agricultural sector serving as a powerful contributor to the country's growth domestic product. In fact, agriculture employs three quarter of the workforce.

However, as argued by Tijan Sallah, The Gambia's weak position as simply 'a price taker', with virtually no influence on what others in the world prepared to pay for its primary commodity, meant that export earnings were particularly precarious, even if/when the hectarage under groundnuts are expanded (Sallah, 1990: 625).

Having attained its independence on that fateful day of February 18, 1965, from Great Britain, The Gambia was hailed as the champion of multi-party democracy in Africa. This was preceded by rocky political developments which witnessed intense agitation for self-rule from its former colonial masters, the British.

In April 1970, a referendum was held in The Gambia, recognising the country as a republic. And Sir Dawda K. Jawara was the country's first ever president (1965-1994). During this era, the country had witnessed relative peace and stability. However, it is worth mentioning that the Jawara regime tasted the bitter pill of a bloody coup attempt in July 30, 1981. The rebellion was led by Kukoi Samba Sanyang against the democratically elected government of The Gambia under President Dawda Jawara.

Until 1994, The Gambia was the longest continuously surviving multi-party democracy in Africa (Perfect, 2008: 435). This actually was an era when countless Sub-Saharan countries were heading towards embracing multi-party political system of governance.

Of course, on July 22, 1994, the Jawara-led government was abruptly ousted from power in a "bloodless coup" engineered by the then Lieutenant Yahya Jammeh and his military associates. Subsequently, Yahya Jammeh metamorphosed himself into a civilian leader contested and won 1996 Presidential election under the regime of the Second Republic.

The reasons advanced for the military-turned civilian leader's victory in the polls, as argued by Perfect, is that the split in opposition ranks, together with the effective campaigning of a pro-government organization, the July 22 Movement, and Jammeh's control over the national media and state machinery. These helped Jammeh secure 56 per cent of the votes cast to the 36 per cent of Ousaniou Darboe, United Democratic Party leader(UDP), Hamat N. K. Bah of National Reconciliation Party (NRP), Sidia Jatta of the PDOIS trailing far behind (Perfect 2008: 433).

Previously, the Jammeh-led military take-over shortly instituted a body named Armed Forced Provisional Ruling Council (AFPRC) which was later transformed into political party, Alliance for Patriotic Re-orientation and Construction (APRC). Among the sterling justifications warranted the military intervention from the viewpoint of the then AFPRC-led force was the former government's corrupt practices. That is President Jawara's People Progressive Party (PPP) which was in power from 1965-1994.

In this period, the country's 1970 Constitution was suspended, existing political parties banned and some government officials under the Jawara regime arrested and detained at the Mile 2 Central Prison. The former president Yahya Jammeh, who contested in presidential elections in 2001, 2006 and 2011 defeated his political opponents with a vast percentage.

The 22-year leadership under Yahya Jammeh was accused of serious human rights violations, lack of respect for press freedom, increasing rate of disappearance without trace and even the emasculation of political opponents. A number of executions have also been alleged to have committed by the regime under Jammeh's orders.

Shockingly, Jammeh's 22-year rule came to an end in December 2016, when he was defeated in the polls by his political rivals, "Coalition 2016" headed by Adama Barrow on behalf of eight opposition parties. The verdict of the people - election results didn't make former president Jammeh to vacate office. He vehemently rejected the election outcome, calling for fresh election to be arranged by what he described as a god-fearing Independent Electoral Commission (IEC). To the surprise of many, he only left office after frantic mediation efforts by the leaders of neighouring West African countries, coupled with an imminent threat of armed intervention should he refuse to cede power.

\subsection{Social Media and Digital Democracy in The Gambia}

Recently, the Internet had begun to receive considerable acknowledgement for the decisive part it played in campaign politics. The rapid rise of digital democracy around the globe has some meaningful lessons to offer. Not only well-rated democratic countries, but far corners of the developing world are also basking in liberating advantages embedded in the internet.

In a digital democracy, some technology optimists are of the belief that globalisation would enable the democratisation of information and decision-making. By this, they meant to explain that citizens would be better informed and that silence will no longer be the deep-rooted norm. The fact is that ordinary citizens will ever be willing to communicate their thoughts to their leaders through the existing digital platforms, especially when face-to-face meetings fail to materialise.

In The Gambia, this is the exact case that had happened and continues to occur in an increasing rate. The newly embraced digital democracy meaningfully helps to enhance participation ranging from civic engagement 
to political participation. The considerable multi-strategies, coupled with the tactical usage of digital media had helped fuel healthy discussions and debates online, particularly on Facebook, Twitter, WhatsApp groups and even online radio programming, etc.

Equipped with Social Media, the citizens no longer have to be passive consumers of political party propaganda, government spin or mass media news, but are instead actually enabled to challenge discourses, share alternative perspectives and public their own opinion (Loader and Mercea, 2011: 759).

In this sense, Social Media could be broadly viewed as a game changer in respect to inclusive and rapid participatory political discussion. Interestingly, just some two decades ago in The Gambia, no one would have ever dreamt of openly commenting on politics, especially if the tunes weren't in favour of the regime in power.

For obvious reasons, the Jammeh government (1994-2016) created an unconducive environment for freedom of expression. During this era, muzzling the mainstream media in the country became a norm. Ordinary citizens became more fearful, engaged in self-censorship as discussions relating to politics or about the government within the Gambian shores had been seen as an untouchable area of discussion for many citizens.

As the silencing trend continues, until July 5, 2013, The Gambia's National Assembly surprisingly passed a bill dubbed Information and Communications (Amendment) Bill, 2013. This allows for a fine of GMD 3 million (about USD\$100,000) or imprisonment for fifteen years or to both fine and imprisonment for anyone convicted of using the Internet to spread false news about The Gambia government or its public officials. As a result of this, many international bodies such as Amnesty International, Reporters without Borders and Article 19 saw this legislation as an outrageous attack on freedom of expression in the country.

Practically, the only remaining viable space for Gambians to freely voice out their thoughts was the Internet space. As such, Social Media apparently became the weapon of liberation for the masses at the time. In fact, many Gambians both at home and abroad resorted to creating pseudo profiles on the Internet more so on Facebook. This was to enable them access certain information revolving around politics back home. One would contest that some of these people couldn't use their real identity due to fear of political persecution whilst many more decided to keep mute over matters regarding politics and governance for their own safety. Politically disenfranchised may be using the Internet to express their concern, potentially offering a pathway to participation for those who feel politically disempowered (Shah et al., 2010). Today, the widespread use of sophisticated smartphones among Gambians has ushered high visibility online. As estimated in 2013 Population and Housing Census report of The Gambia that, 79.1 per cent (9.8 per cent- males and 78.6 per cent females) have access to mobile phones. Additionally, the proposition with access to computer has been pegged at 10.9 per cent (Gambia Bureau of Statistics).

Patti et al. postulates that Social Media has the potential to bridge the gap between public administrators and citizens. He further expounds that citizens' use of Social Media can give a real-time picture of their opinions and perceptions of state matters and thus can inform planning and policy (Patti et al., 2017).

2016 which marked a watershed moment in the Gambia's political history, for it was the presidential elections that year that ended Jammeh's grip on power. It was decisive year indeed a decisive moment. Many Gambian citizens were involved in online campaign in a manner never experienced in the digital space. Discussions often revolved around politics, life-style and campaign methodology, etc. Also, online petitions became a powerful tool for individual resistance towards their government's mal-administration back home.

In their search for a saviour, in an intense political climate, Gambians far and near having individually reassessed the country's future came to the realisation that the only available option at their disposal was to amplify their voices via Social media platforms such as Facebook, Twitter, WhatsApp, etc. With the hashtags: \#GambiaDecides and \#FreeGambia went viral in social media ecology.

Obviously, this mobilisation initiated on social media infrastructure was aimed at effecting leadership change and to usher in democratic values for citizens. Considerably, this is what resulted in the change of political leadership in December 2016 in The Gambia.

Similarly, the quest for change is what propelled certain movements. Also, as argued by Adeola, "Arab Spring" in countries like Tunisia, Libya and Egypt their difference with the case of The Gambia was that in The Gambia organised political structures were set up. And it was through these that Adama Barrow-led "Coalition 2016" won the December 2016 presidential election (Adeola, 2017).

Another historic day worthy of mentioning is October 30,2016, a day that gave birth to the official declaration of the then opposition parties' candidate, Adama Barrow under the flagship "Coliation 2016". It was no easy ride for them with limited if any media coverage accorded to the opposition parties in those trying moments whilst the then incumbent Yahya Jammeh was enjoying the advantage of having the state-controlled media (GRTS-Television and Radio). Literally, these moments were characterised by massive media blackout for the opposition to get across their messages to the masses.

On the other hand, only online channels such as Eye Africa online TV was broadcasting from The Gambia plus other online Gambian radios, for example, Freedom Radio, Fatu Network Radio, Gainako Radio and online newspapers mostly based and run by Gambian dissidents in America and Europe. In this way, a considerable 
number of Gambians during this time followed and had access to information about political matters on the home front.

It is no secret that in Gambian politics today social media flows are becoming a decisive element toward participatory governance. Nowadays citizens are seen as not mere passive recipients of state information as the case used to be few years ago. Indeed with the status-quo, the extensive use of social media sharply increases citizens' participation as key stakeholders in shaping policies or decisions by those in positions of authority.

In this end, social media has encouraged a more civic participation in voicing people's thoughts among Gambia's online community. For example, prior to the country's election citizens increasingly took to social media platforms such as Facebook to interact and talk politics. A group named The Gambia Youth and Women's Forum at one point attracted a membership of 55,000 people. Also, WhatsApp groups like Concern Gambians were all part of media used for information sharing among friends and family in extending political messages to the masses in The Gambia before election.

\subsection{The Research Problem}

Many essential literature on social media influence on election results in The Gambia uncover a research gap which requires further exploration. In the case of The Gambia, social media resonated well with the political consciousness of a teeming mass of Gambian voters in the December 1, 2016 Presidential polls. As widely believed it brought an end to 22-year dictatorial regime overnight in the West African nation.

And whether it has any meaningful impact on the mind-sets of ordinary citizens in passage of crucial decisions like in the political arena. Again, as a result of increased social media usage for information consumption in the public space, the curiosity of this study interrogates this question, can it translate into massive voter turnout in elections as a prime case of The Gambia?

The hypothesis: young people using social media mostly voted for "Coalition 2016" in The Gambia presidential election.

\subsection{The Objectives of the study}

Understandably, social media influence on elections cannot be underestimated. For this reason, it would be of great importance for research investigation to be shifted towards this area. Considering the on-going debate in the scholarly discourse in which many credited the expansion and growth of social media and innovation usage mostly in electoral processes.

However, the exploratory journey toward political impact of digital media is yet difficult to assay. This is the curiosity aspect this research intends to uncover whether the claim it bears is applicable to Sub-Saharan African countries like The Gambia or not. Specifically whether social media has indeed influenced the mind-sets of ordinary Gambian voters in the December 2016 elections.

Again, not to forget studies paying keen attention to local context and cultural factors such as social divides, standard of living, education status and language should provide a more fruitful and rich understanding of the phenomena at hand (Enli and Moe, 2013: 641-42).

Moreover, the research objective does not only serves as a bedrock in the study of The Gambian media landscape as a developing country but additionally it intends to set the ground topic for emerging scholarship on the subject of discussion.

\subsection{Research Questions}

Based on on-going phenomenal discourse about social media influence on elections or political realm outcome, it is very essential in a number of ways to interrogate certain research questions in the scholarly debate. To arrive at more clear findings on the research area, we need some questions which indeed require answers. The following research questions will be used to guide this study:

1. What are the attitudes and beliefs of Gambian youths concerning the use of Social Media in politics and the raising of political consciousness?

2. What motivated voters to vote in The Gambia's 2016 election?

3. What influence, if any, does Social Media have on voter behaviour and choices in the Gambia's 2016 election?

4. What role if any, did Social Media play in raising political consciousness for political change?

\subsection{The Structure of the Thesis}

This thesis write-up is being divided into various chapters. In chapter one, it briefly explains socio-economic and political landscape of The Gambia with a view to giving an idea about the country's geopolitical insights. It also discusses the significance of the research on social media influence on political consciousness in Sub-Saharan countries, with a specific case of The Gambia. It further argues the rationale for this finding.

Chapter Two reviews essential literature on social media and its effects on election outcomes. Also, this 
section attempts to critically look at existing literature on social media proliferation in Sub-Saharan African countries.

In Chapter Three, the research methodology describes the research method and techniques employed and how data were collected and analysed. Chapter Four, this section discuss in detail the data analysis tool used to establish the main findings of the research.

Chapter Five, which is the final section draw a summary and conclusion of the research project. This part also highlights limitations of the study and further suggest some likely areas for future research curiosity to be explored by emerging scholarship in the subject matter. And of course, finally it draws a conclusion on the overall work.

\section{REVIEW OF LITERATURE}

The essence of the review of literature in this section is to basically establish a research gap that would necessitate a focus investigation. Also, it tries to point out available key research findings as previously captured. Further, this section seeks to do a comprehensive review of literature on certain sub-headings as a way of deepening specifications in the search for literature and consequently establish a research gap.

\subsection{Social Media and Political Mobilisation and Activism}

Social media has been utilised for political mobilisation across the globe. For example, from Egypt, Iran, Iraq, Tunisia and Kenya. In fact, the Egyptian revolution seemed to have the larger scale mobilisation based from social media (Mutanana, 2016). Accordingly, as per view advanced by Mutanana (2016) considered social media as an effective tool for communication which has positive effects on political mobilisation crusade. Also, prior findings suggest that social media has dramatically changed the landscape of mass mobilisation and politics in a renowned fashion. That to large extent enables people to hold their leaders accountable (Mngusuul, 2015).

Scholarly literatures have also extensively elaborated on the creativity often times exerted by activists on social media platforms in their quest for mobilisation. For instance, during political campaigning and fund raising moments.

Digital activism has rapidly enabled by the new media and more specifically the phenomenon of social media (Chibita, 2016: 71). As Chibita puts it, using mobile phones people used multi-media approach - which involves upholding audio, photos, video clips, etc., from the political campaign trail. Furthermore, studies carried out indicate that social networks sites are indeed engaging young people in both civic and political activities. Kamau (2016: 127) collaborates this view stating that social media is very effective in raising awareness and ensuring exposure of young people to information about social causes. Additionally, the influence of social networking sites will increasingly rise as many people join social media platforms with access to internet (Kamau, 2016: 132).

Giving the fact that several active movements do use online platforms to complement their offline activities and engagements, some researchers argue that as access to internet penetration grows bigger, the engagement of people will become manifest from the dimensions of civic and political sphere as a whole. Social media play an important role in facilitating the mobilisation for, and coordination of direct action offline (Cammaert, 2015: 5). Arguably, social media could be rightly said to have the capacity and of course creativity that would help activists to spread organisations and movements goals easily.

In one of the renowned thorough comparative studies, Manuel Castells in his book Networks of Outrage and Hope argues that seeing and listening to protests somewhere, for example, in distant context and different cultures actually inspires mobilisations. In this way, he adds in fact triggers hope of the possibility of change (Castells, 2015: 252). Lim (2013) states that understanding the nature of social media activism coupled with its conditions for success. Recommends that activists could utilise, employ and transform it into essential civic engagement and political participation (Lim, 2013: 654).

Dimitrova et al., (2013) postulates that voters increasingly rely on media for political information. Accordingly, certain factors such as political knowledge and candidate image - constitute an instrumental aspect for passage of vote choice.

Media use has the potential to shape political engagement (Boyle and Schmierbach 2009: 4). Conversely, research findings did suggest that the internet too can play an essential role when it comes to community building. For instance, serving pivotal role in enhancing both social and political involvement (Boyle and Schmierbach 2009; Noris 1998; Shah et al., 2001). Gibson et al. (2004: 5) reveal that from individual viewpoint ICTs should be considered as a tool for political socialisation, particularly among the youthful citizens. In this regard, he also argues that we shouldn't rule out the internet as a potential means of politicisation for individuals.

In Indonesia, for example, just like what Lim (2013) coined "cyber-civic space". As Lim argues both individual and group generate collective activism from online space and onwards translate it into real-world movement in an offline setting (Lim 2006; 2013).

The positive communicational outcome usage of social media for protest purposes has reportedly been 
regarded as powerful. And subsequently, in fact it saw both certain authoritarian regimes and democratic governments impose some measures to control the internet. For instance, the then Mubarak government in Egypt did cause an internet blackout by literally switching off the internet for five days (Theocharis et al., 2012; Glanz and Markcf 2011). Theocharis et al., (2012) postulates that the internet has profoundly transformed two elements of traditional protest mobilisation: participation cost and the need for co-presence. Some empirical investigation results has also shown that theoretical observations have oftentimes worked well in protest mobilisations (Bernett and Segerberg 2012; Mercea 2012; Theocharis et al., 2012).

Further, previous study conducted by Meti et al., (2015) in India indicates that social media for political activities influences peoples' political efficacy, political knowledge and even political participation as a whole.

Also, social media can be a valuable medium for political mobilisation. For the reason that technologies could empower citizens and mitigate the top-down politics, especially in scenario where leaders control the narrative of information and decide for people (Mosharafa, 2012). Moreover, findings shown that personal appeal can affect voter mobilisation without even shaping voter attitude (Mosharafa, 2012; Suarez, 2010).

Some scholars like Mosharafa wholly held the belief that social media can meaningfully aid in the process of recruiting members and activities for politics. For example, in terms of spreading political messages, mobilising potential voters and organising support in political campaigns.

In this sense, both Shirky and Mosharafa also argue that social media serves as coordinating infrastructure for almost all the world's political movements. And by extension, becomes a tool for democratisation as it helps in toppling regimes (Shirky, 2011; Mosharafa, 2012). Again, in political mobilisation crusade, it is forecast that social media will continue to enable tremendous impetus for greater political agitation. In this way, developing societies like the African continent would be able to both express and mobilise its people to transform it societies for good.

In summary of this section, a thorough review of relevant literatures mostly reflect the viewpoint that usage of social media sites could enhance tremendous political mobilisation and activism. Nonetheless, there are some presented arguments as certain literatures hold a contrary views. For example, the internet and political participation suggest that the internet had failed to increase political participation as acclaimed by technooptimistic (Bimber, 2001; Cammaert, 2015). In essence, as for some sceptical perspective viewpoints, even though the sophistication of social media is hailed for effecting political change, there are some limitations to this claim. For instance, internet penetration range, economic capabilities of people, the digital divide among other factors inherent in technology.

\subsection{Social Media and Political Consciousness}

The political awakening and growth of political consciousness of a society is an indispensable tool for enlightened mass citizens. Essentially, political consciousness of a people is being regarded as a fundamentally necessary ingredient for a passage of well-thoughtful political decision, especially in exercise of crucial duties like elections.

Political consciousness to a greater extent could be viewed as perception and idea base of an individual that is associated with politics. And most significantly, activities like action framework of political sphere (Balue and Kaminchenko, 2015).

Some researchers like Boulianne argue that the effective use of SNS can enhance participation and engagement that shapes public narratives for comprehension of public affairs (Boulianne 2015). Social media use enhances socio-political awareness ranging from political knowledge to motivation for political activities (Amin and Mahmud, 2017).

Further, studies showcase that platforms such as Facebook increases one's political consciousness or political knowledge due to political and civic discussion often carried out online. Social media platforms as userfriendly cultivate political consciousness among its users (Geoff et al., 2012; Gil de Zunigal, Molyneux and Zheng, 2014).

Arguably, Gil de Zunigal et al. (2014) in their findings also confirm that political expression through social media platforms is indeed promising for the development of a politically active future. For instance, the younger people are seemingly active users of social media outlets.

Political opinions and political behaviours, according to Castells et al., (2005) are constituted in the space of communication. Balue et al., (2015) in their findings also reveal that social media can help in shaping and changing attitudes of both social and political institutions.

In this sense, it can be said that social media could enhance people's level of involvement in social and political affairs. In this regard, increased use of social media outlets by citizens for active engagements in meaningful political discourse is likely to shape people's perception towards issues revolving around domestic politics and policy dimensions. This, in turn could greatly help the overall betterment of a particular society.

As often argued by certain scholars that political consciousness and participation seems to be very low in some societies primarily due to the level of political apathy. In this regard, social media active users who mainly 
constitute the youth often tend to meaningfully use it to chart out their future in a more engaging and productive manner.

Equally, politicians use social media extensively to strengthen their ties with the electorates, provide information about their political stances and further attracts participation (Cakar Mengu et al., 2015). Also, people use social media not only to access online versions of offline content, but to generate original content themselves, thus creating new forms of political participation (Gil de Zunigal et al., 2014: 613).

Baluev (2013) posits that so-called social media have been taking an independent political role. And fundamentally becoming a critical tool for political change. Cakar Mengu et al., (2015) also argues that social media in broader sense appears as a crucial element for not only forming an organization for the public. But it enables participation in these organizations by increasing their level of both consciousness and awareness creation as a whole. There are often political campaigns conducted with the help of social media helps to attract new supporters (Baluev, 2013).

Apparently, the media are being harnessed to increase awareness level of people and more so the understanding of democracy in many parts of the world including developing nations. For example, information technology is used to draw people attention into political participation (Farnen et al., 2014).

\subsection{User-generated Content and Election Campaigns}

User-generated content could be described as content created by users in a particular given topic. In social media platforms, it enables political related craft content in forms of digital audio, visual art, text format and sound to be shared from one personal network of contact to a more viral mood. This eventually reaches several audience for a consumption of the shared message.

For instance, Facebook, WhatsApp, YouTube and Twitter often help users to interact among themselves with the help of generation and share basis of content. Noticeably, the digital age recently has sparked a dramatic change in number of human activities ranging from pattern of news consumption to political discourse, etc.

A body of empirical research demonstrates that the use of social media for election campaign is significantly on the increase. There are considerable evidence that both incumbent parties and struggling opposition parties are making increasing use of social media tools as a way of promoting their messages and candidate manifesto to electorates (Bright et al., 2017: 3).

The Internet doesn't only serve as a vehicle for attraction during campaign periods, but in some aspects is far better than the offline communication format (Bimber and Davis, 2003: 20). From a broader perspective, user-generated content seems to be greatly changing the media landscape in number of ways. In the sense that, it has the potential in affecting how media content is both consumed and produced to a larger scale. Interestingly, some studies suggest that the principal reason for using social media platforms by politicians and political parties during election campaign phase are related to voter mobilization, marketing of their manifestos and ensuring dialogue to occur.

Davis (2014: 2) adds that social media in fact can be used in election campaigns to mobilise supporters and further convince those uncommitted voters to vote. Similarly, user-generated content in essence help political candidates to be able to bypass the mainstream media production routines. As a result, it gives candidates the leverage during election campaigns to attract supporters who themselves produced, upload videos and photos from the campaign trail about a specific candidate and/or political party (Davis, 2014).

Bright et al., (2017) postulates that indeed social media have the power to enable "personal connection" between a candidate and their prospective voters. Additionally, it is argued that there are possibility of direct engagements to occur when social media sites are used between politicians and voters. In the contrary, this couldn't be possible accordingly through the mediated mainstream news media.

Election campaigning through social media platforms actually gives voters some sense of feeling and opportunity to be able to connect and interact with politicians (Lee and Shin, 2012; Howard et al., 2017: 7). Internet enhances campaigns quickly. In this way, nowadays internet election campaigning are deeply embedded in politicians party's approach (Stromer-Galley, 2014: 118).

Furthermore, certain researchers in their findings show that social media use could genuinely ensure crucial difference to electoral campaigns. In this respect, review of literatures also confirms that some previous elections indicate how social media were employed as a means to a political advantage.

Consequently, the trend of user-generated content approach such as retweeting fashion continues to grow bigger. In the same way, the shared messages also attract some considerable amount of viewership and readership as a whole.

Arguably, the visibility of a politician or a political party via a particular social media platform and their activeness in posting valuable messages that are deemed relevant to electorates is likely to boost followership. However, user-generated content campaign message sharing could only be meaningful and effective when suitable voter populace are visible in a particular social media platform where these messages are been shared. In fact, it has been argued that a great deal of politicians most often only go to online to appeal for endorsement 
from potential voters, especially during election season.

\subsection{Effects of Social Media on Election Outcomes}

Several scholarly works including Soeung (2013) posited that social media in actual sense has aided more nascent and pluralistic online political environment in a manner that it facilitates and strengthens divergent political viewpoints. A forecast was drawn that possibly such an emerging crucial political engagement during campaigns such as critiquing and intense political discourse could impact on the political behaviour of the younger generation overtime.

Some studies supported the claim that mass media including the social media has the potential to influence voter attitude, especially when it comes to crucial moments such as election campaigns (Alotaibi, 2013: 7). Ahmade et al., (2017) reveals that social media is an influential platform that can shape opinions. Arguably, it creates the ground for more critical discussion to emerge among the citizenry and even politicians as a whole.

Prior studies have also sought to critically examine the political dimension of social media sites and have explicitly argued that often politicians do use social media platforms when seeking for political job. It continues that of course is a potential indicator for electoral enthusiasm (Fernandes and Bowes, 2010; Jackson and Lilleker, 2004; Utz, 2009; William, 2008; Bode et al., 2004).

In communication mediation model for instance, it is argued that different dimensions of the media usage, notably newspaper reading, television viewing and online surfing for news consumption all in one way or another bears certain degree of successful gains towards political participation to a greater sense (Bode et al., 2014: 417).

In a specific reference to Barack Obama's electoral success in his 2008 and 2012 Presidential campaigns, social media platforms are hailed for the indelible mark they have left in that regard. To simply put it, due to certain creativity been injected onto the Internet, the influence of social media specifically has received certain magnitude of credit by virtue of its role in reaching out to potential voters and aiding in sharing of relevant campaign messages to wider recipients.

As put by Cameron and Barret (2014: 4) winning in elections is complex as there are several factors associated with electoral victory itself. To this end, they argue key to this electoral victory has to do with the advantages of "incumbency effect".

\subsection{The proliferation of Social Media in Sub-Saharan Africa}

The media landscape in Sub-Saharan Africa is rapidly changing in several forms. These changes are being manifested in numerous ways ranging from the traditional format of news presentation to its consumption by the audience.

Several literatures did argue that social media is playing an instrumental role toward a positive social change. The new media indeed have become an integral part of political communication in Sub-Saharan Africa, irrespective of the situation in the individual countries (Windeck, 2010: 37).

In a broader view, it is worth mentioning that social media use have somehow altered the fashion of democracy in Africa. Indeed, this is promising and at the same time multi-faceted altogether. However, it must also be acknowledged that it goes along with it constraints as well. There is a paradigm shift in narratives and every good indication that Africa is slowly heading to right direction as far as freedom of expression via the Internet is concerned (Kalyango et al., 2013).

The increasing growth of social media usage in Africa continues to take it shape in the empowerment of the citizens' voices. In the wake of the so-called 'Arab Spring' the power of social media did serve as a springboard in mobilizing people and further attraction of political pressure- perhaps one fundamental course being undertaken by Africa- which serves as global reference point in bidding farewell to its long-serving dictatorial regimes in countries such as Tunisia, Egypt, and Libya.

This fashion of growing upsurge in youthful protest crystallized in strongly worded is "Enough!" to dictatorship rule; an unexpected protest borne out of long-standing struggle for both political, social and economic emancipation of citizens.

On the political front, the direct interaction between citizens and politicians via social media platforms such as Facebook and Twitter is unprecedented. This interactions have broken deep-seated political barriers, and the traditional culture of fear associated with publicly challenging the political elite has been deflated, albeit in dispersed digital spaces (Mabweazara, 2015: 2).

An exemplary scenario to this, was the case in October 2014 in Burkina Faso. Social media was used by ordinary citizens to avert Burkina Faso's ex-president Blaise Campaore from changing the country's constitution to avail himself an opportunity to run for an additional term in office after his 27-year rule ends.

In this sense, we can contest that the Internet and social media of course have become the frontier for the swift contestation of political power and democratic expression for not only in Africa per se, but across the world. The booming popularity of Internet users in the horn of Africa which is been pegged at 31.2 percent as of 2017 
(Internet World Stats) is noteworthy. This shows some significant degree of Internet dependence for multi-usage. Among them information sharing purposes.

Interestingly, the discovery of social media as a tool for political mobilization didn't only give political elites a platform to showcase and propagate their ideologies, but it also offered ordinary citizens the opportunity to actively participate in healthy political discourse.

To interact with one another through Twitter feed, Facebook posts, share and comment format, for example (Kiranda et al., 2016: 41). Previous studies carried out in some parts of Africa, notably North Africa- Egypt and Tunisia indicate that the Internet and Mobile phones are relevant tools used in social media communications. Also, it adds that our political conversation sequence has increasingly changed due to existing social media sites. These are mostly used and accessed by citizens.

Social media has proved effective in dissemination of information on human sufferings in despotic and illiberal regimes notwithstanding its inherent shortcomings associated with it as a technological platform (Chidi and Chimee, 2016: 12).

In modern day, in many developing countries, especially on the African continent, we live to experience sharp increase use of social media outlets in championing political communication such as in national elections campaigns.

This tends to be somehow visible in a number of developing economies and nascent democracies of recent. In this regard, the use of social media by politicians seeking elective office is significantly overwhelming. Kamp et al., suggest that the intense activities on social media platforms may provide channels for quickly reaching out to the public, especially supporters and potential voters (Kamp, 2016: 24).

Kenya is a prime example of countries in Sub-Saharan Africa that live to experience frequent use of social media in its political gamut. A manifestation to this, was the 2007, 2013 and 2017 Kenya's Presidential Elections respectively that heavily utilized social media platforms such as Facebook and Twitter by political parties to further their manifestos to potential voters as well as the post-electoral conflict that hit Ivory Coast in 2010 disputed Presidential Election between the then president Laurent Gbagbo and his political rival now president, Alasane Ouattra., social media was incorporated and used at both political campaign phase and post-electoral era.

Apparently, Alassaane Ouattra's social media team successively tweeted appeal pointing out how Ouattra's regime was recognised and widely accepted as the sole legitimate authority of Ivory Coast by the International community (Iwata, 2015: 52).

Furthermore, research has profoundly shown the intensity of usage of social media in political scene in SubSaharan nations like Mali for instance, during its coup d'état and post-coup democratic transition 2012-2013 Presidential Election -a well contested election between Ibrahim Keita and Soumail Cisse as standard bearers. During this period, the aforesaid candidates were able to sell out their candidature to voters by simply incorporating in their traditional campaign strategy, social media innovation. Many African political leaders nowadays have become aware of social media's power to gain them political influences or to threaten their political superiority (Iwata, 2015).

In essence, in countries where freedom of speech and press is being trampled upon and more so lack of functional independent media social media tend to give voice to the people. The Kenyan example clearly illustrates that new media can be a crucial tool to support democracy and transparency in developing countries, especially if the media are caught between lack of press freedom and premature self-censorship on the other hand (Windeck, 2010: 27).

In spite of the due consideration and heralded praises being directed toward social media for significantly altering the political discourse and its electoral results, there are certain pessimists who are doubtful about the praises it generated recently. As a matter of fact, previous scholarly search works are increasingly divided over this issue at hand. That is the influence of social media on electoral success outcomes.

Crucially, considering certain essential factors that had to do with geographical basement, things like exposure to social media sites and the overall utilisation by politicians in their quest for awareness creation and enlightenment drive as a whole would undoubtedly help in establishing the truth associated with its effective role it might have had on average voter behavior among others.

Comparatively, the usage of social media tools for election campaigns might have worked successfully well for some countries in the developed world such as the United States of America as demonstrated in both 2008 and 2012 presidential elections. On the other hand, the opposite is the experience for certain nations as it been depicted by a vast body of literatures due to it ineffectiveness in attracting potential voter populace. As the case study of Philippines 2013 election in particular indicated.

Therefore, the possibility of social media influencing the political decision and its leadership is evolving in scale. It enables citizens to boldly articulate and debate about considerable political feelings that are geared towards promoting societal development.

However, needless to say, it is certain that in some scenarios one may view such articulation of individual feeling vastly impossible to occur away from social media platforms. The simple reason is that been the doers of 
the actions either face arrest, charges or imprisonment.

Having conducted a comprehensive review of essential literatures on the subject matter: social media and elections related, it is quite prudent to establish the increasing attention drawn by social media and the much heralded and effective role it plays in ensuring both social and political interaction to occur.

Nevertheless, what actually remains unclear is about the through potential and factors that enhance social media utilisation in electoral success outcomes, particularly for a classical nascent democratic Sub-Saharan African country like The Gambia, deepening into findings to establish whether social media had actually aided in effecting a regime change in the 2016 Presidential election. That oversaw the abrupt defeat of the 22-year incumbent government of Yahya A.J.J. Jammeh overnight bearing in mind all the incumbency opportunities at his disposal, especially when it came to the mainstream media, which was virtually at the dictate of his government, state-owned media (Radio and Television) to be specific. This raised the question: Did social media influence the mindsets of the ordinary voters in their electoral choices and voting behaviours that affected the electoral outcome?

In this end, the aforesaid established a research gap which seeks to investigate and provide tangible answer to this search. Further, cognisant of the fact that in other parts of the developed World social media and elections have been studied at a wider scale. However, in the case of The Gambia as a nascent democratic establishment, this area under investigation is non-existent, very young and the same time unique in totality.

\section{RESEARCH METHODOLOGY}

In chapter four, in research methodology - it describes the research method and technique employed and how data were collected and analysed.

\subsection{The Quantitative Approach}

\subsection{Data Collection Techniques}

The current research investigation is specifically based on descriptive research design. The data collection approach employed was quantitative method (descriptive design). Based on this approach, it seeks to understand how social media influenced political behavior and shapes individual voting choices at 2016 presidential election of The Gambia. As a way of getting insights into voters' usage of social media such as Facebook, Twitter, WhatsApp among others and how it might have influenced the political thoughts of people.

A primary data was directly gathered from respondents. This was carried out through a study conducted using survey questionnaire that was entirely carried out offline (manually) in The Gambia among Gambian voters as principal respondents. 300 structured questionnaires which had eighteen questions were distributed and administered in The Gambia. The question format contained mainly a closed-ended multiple-choice questions, among them demographics and scaling type format. Additionally, the process of the data collection commenced from $10^{\text {th }}$ August to $30^{\text {th }}$ September, 2017.

Looking into the intensity of the data distribution strategy the study was specifically focused in three main regions-Banjul (capital city), Kanifing and Brikama (Local Government Areas). These are all located in the urban centres. The questionnaire was distributed in those regions whose total population constitutes the following figures. Banjul, 31,301; Kanifing, 382, 096 and Brikama, 699,704 respectively. The country's total population is been pegged at 1, 959,536 (Gambia Bureau of Statistics 2013 Census).

Within this captured scope, 287 pre-prepared structured questionnaires were filled by respondents whose age grades range from 18 years and above. The research questions exclusively targeted only those eligible potential voters who are qualified to vote under the Gambian electoral law. In their bid to shed some light on how social media might have influenced their voting behaviours and choices in passing crucial decision at the presidential election 2016. However, the random sampling technique employed during the data collection doesn't involve unqualified voters during the election period.

Additionally, the research also made use of both primary and secondary data ranging from published books, journals to survey data accessed from relevant departments and/or offices both within and out The Gambia.

Further, the study methodology used to analyse the data collected was Statistical Package for Social Sciences (SPSS).

\section{RESULTS AND DISCUSSIONS}

Chiefly, this chapter intends to enter novel discuss on the research findings. It further provides some answers to the main research questions that necessitated this present investigation from the outset. Most significantly, the study also demonstrates some perspective as a way of contribution to already existing literature on social media and election dimension.

A total of 287 respondents in 2017 in the Gambia who have voted during the Gambia's 2016 Presidential Election were recruited for the study with all of them participating, thus, giving a response rate of 100 percent. Respondents were recruited electorates in 2016 Presidential election. The results were presented in sections listed below in line with the specific objectives of the study: Socio-demographic characteristics of the study 
population, respondents' motivation for voting behavior, respondents' social media platform preference, respondents favourite political party, socio-demographic characteristics and political affiliation and sociodemographic characteristics and media.

\subsection{Socio-demographic Characteristics of the Study Population}

Table 1 summarises the socio-demographic characteristics of surveyed participants by age. Towards the research exploration from the outset, it is well conceived that the legal voting age grade as outlined by the Gambian electoral laws commence at 18 years old. For this reason, surveyed respondents were rightly captured for those ages ranging from 18 to 60 years and above. As a way of including as much as different age category into the study for a fair representation of all eligible voting populace.

Table 1: Socio-demographic of respondents

\begin{tabular}{lccc}
\hline Variable & & Frequency & Percent \\
\hline Age & $18-25$ & 82 & 28.6 \\
& $26-32$ & 103 & 35.9 \\
& $33-40$ & 55 & 19.2 \\
& $41-60$ & 41 & 14.3 \\
Gender & $61+$ & 6 & 2.1 \\
& Total & $\mathbf{2 8 7}$ & $\mathbf{1 0 0}$ \\
& Male & & 58.2 \\
& Female & 167 & 41.8 \\
& Total & 120 & $\mathbf{1 0 0 . 0}$ \\
\hline
\end{tabular}

The results indicates that 28.6 percent of the respondents falls within the age category of 18 to 25 years old ( 82 respondents). Further, for those who are graded between 26 to 32 years (103 respondents) constituted some 35.9 percent (Table 1).

Also, among the surveyed participants who age from 33 to 40 years old (55 respondents) scored 19.2 percent. Furthermore, those between 41 to 60 years (41 respondents), according to the results made up some 14 . 3 percent. Some numbering of 6 respondents whose ages range from 61 years and above accounted for 2.1 percent of the scores.

Essentially, the highest degree of respondents by age according to the findings fall between 26 to 32 years ( 35.9 percent). This is closely followed by those between 18 to 25 years old ( 28.6 percent). Of course, the smallest scale been registered stands at 2.1 percent which is been attributed to those respondents between 61 years and above of the voting members.

The result showed that, male were 167 (58.2 percent) and the number of the females were 120 (41.8 percent) which gave a total of 287 (100 percent) respondents.

Considering the majority of those who voted for the Coalition 2016, for instance constitutes the young people compared to the elderly population who voted. Owning to the fact that, The Gambia is predominantly a youth dominant society.

The population of The Gambia is mainly constituted by young people. About 63.55 percent of the population are below 25 years (Gambia Bureau of Statistics, 2013). For this reason, it could be greatly attest that most of those who were active social media users are young people.

\subsection{Respondents Motivation for Voting Behaviour}

It was quite interesting to established some behavioural phenomenal among the voting populace, especially when passing a crucial choice to elect their favourite candidates for leadership. The current search has establishes that the greater percentage of respondents who voted in The Gambia 2016 presidential election. Majority of the surveyed respondents about 73.2 percent (210 respondents) did indicates that they were highly overwhelmed to vote due to the fact that they simply wanted political leadership change (Table 2).

Table 2: Motivating Behaviour of Respondents Voting

\begin{tabular}{lcc}
\hline Variables & Frequency & Percent \\
\hline Political Party Leader & 32 & 11.1 \\
Nature of Political Campaign on Social Media & 21 & 7.3 \\
Wanted Political Leadership Change & 210 & 73.2 \\
None & 24 & 8.4 \\
Total & $\mathbf{2 8 7}$ & $\mathbf{1 0 0 . 0}$ \\
\hline
\end{tabular}


Figure 1: Pie Chart Showing the Motivating Factor of Voting During the Elections

\section{Motivating behaviour of respondents voting}

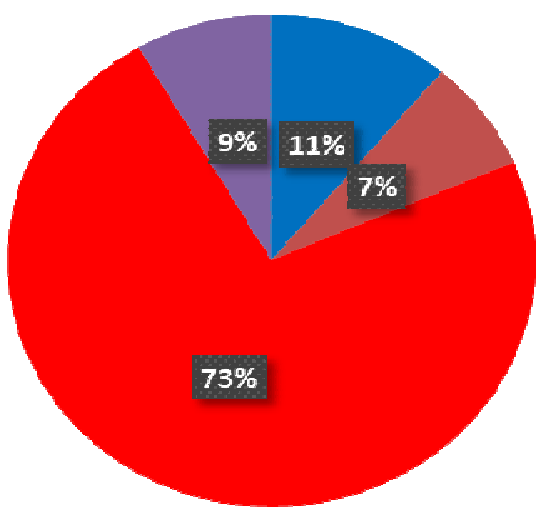

- Political Party Leader

- Nature of Political Campaign on Social Media

- Wanted Political Leadership Change

None

The figures above provides crucial reasons what motivated the sampled voters as respondents to vote in the election (Figure 1).

Furthermore, certain range of 11.1 percent (32 respondents) divulged that they were motivated to vote purposely because they like a particular political party leader. For the political party they have voted for. Meanwhile, other percentage of 8.4 percent ( 24 respondents) suggests that they voted due to none of the reasons stipulated in the questionnaire. This demonstrates that certain member of voters truly build confidence in voting processes.

In one way or another, could be measure as their weaponry tool for determining the type of future rule or leadership fashion they want to be governed and associated with.

Accordingly, the research results accounts that some 7.3 percent of 21 respondents mainly casted their votes for political party based on their reference to what could be described as nature of political campaign been mounted on social media platforms. The aforesaid representation sought to answer voters' motivation to vote during the December 2016 presidential election of The Gambia.

\subsection{Respondents Favourite Political Party}

The table below describes the political of the respondents, it has been showed that the Gambia Democratic Congress (GDC) had 36 (12.5 percent), Alliance for Patriotic Re-Orientation and Construction (APRC, former ruling party) had 43 (15.0 percent) and the Coalition 2016 (COA) had 208 (72.5 percent) (Table 3).

Table 3: Respondents Favourite Political Party

\begin{tabular}{lcc}
\hline Variables & Frequency(n=287) & Percent \\
\hline Gambia Democratic Congress (GDC) & 36 & 12.5 \\
Alliance for Patriotic Re-Orientation and Construction (APRC) & 43 & 15.0 \\
Coalition 2016 (COA) & 208 & 72.5 \\
\hline Total & $\mathbf{2 8 7}$ & $\mathbf{1 0 0 . 0}$ \\
\hline
\end{tabular}

\subsection{Socio-demographic Characteristics and Political Affiliation}

The cross tabulation table below of the study revealed that more than half of the males respondents 23 (63.9 percent) voted for Gambia Democratic Congress (GDC), followed by Coalition 2016 (COA) 122 (58.7 percent) and Alliance for Patriotic Re-Orientation and Construction (APRC) had 22 (51.2 percent). These differences were not statistically significant $(\mathrm{p}=0.504)$ (Table 4$)$.

Table 4: Cross tabulation of the political party against gender of respondents

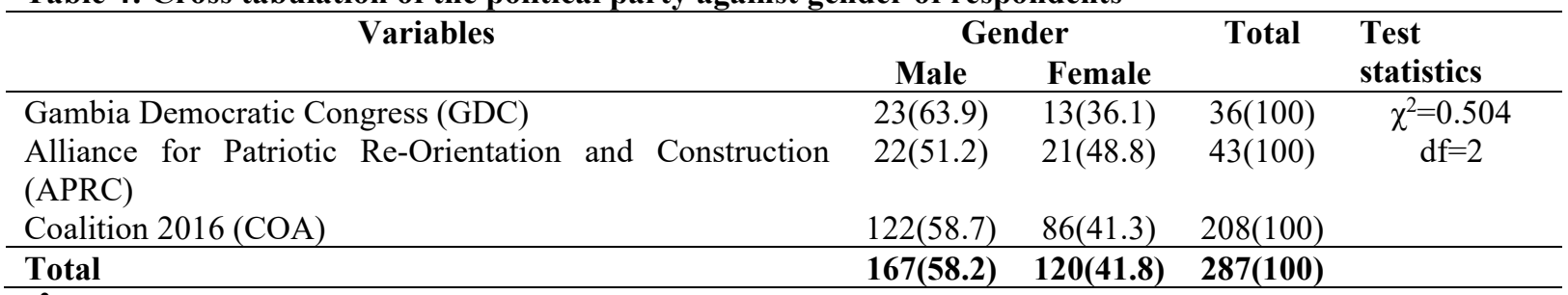

$\chi^{2}=$ Chi square

Substantially, it also worth to note that results figures of The Gambia last presidential election shows that out of 886,578 registered voters in 2016 election. 525,963 voted casted by the voter populace. The "Coalition 
2016" led by Adama Barrow pulled out 227,708 (43.29 percent), Yahya Jammeh, the then incumbent (APRC) received 208,487(39.64 percent) and followed by Mamma Kandeh (GDC) 89,768 (17.07 percent) of the votes (Independent Electoral Commission, 2017).

According to the present research, it was able to prove the above. For the fact that, the respondents favourite political party exactly displayed as the above.

\subsection{Socio-demographic Characteristics (age) and Political Party}

Statistically, the revelation in this study found that more young people between the ages of (18-25) and (26-32), 30.3 percent and 38.9 percent respectively. Voted for the Coalition 2016. Compared to other political parties such as APRC (the then incumbent government) and GDC (Table 5).

Table 5: Cross Tabulation of the Political Party Against Age of Respondents

\begin{tabular}{|c|c|c|c|c|c|c|c|}
\hline \multirow{2}{*}{ Variables } & \multicolumn{5}{|c|}{ Age } & \multirow{2}{*}{ Total } & \multirow{2}{*}{$\begin{array}{l}\text { Test } \\
\text { statistics }\end{array}$} \\
\hline & $18-25$ & $26-32$ & $33-40$ & $41-60$ & $61+$ & & \\
\hline $\begin{array}{l}\text { Gambia Democratic } \text { Congress } \\
\text { (GDC) }\end{array}$ & $12(33.3)$ & $9(25.0)$ & $7(19.4)$ & $6(16.7)$ & $2(5.6)$ & 36 & $\chi^{2}=0.022$ \\
\hline $\begin{array}{l}\text { Alliance for Patriotic Re- } \\
\text { Orientation and Construction } \\
\text { (APRC) }\end{array}$ & $7(16.3)$ & $13(30.2)$ & $9(20.9)$ & $12(27.9)$ & $2(4.7)$ & 43 & $\mathrm{df}=8$ \\
\hline Coalition $2016(\mathrm{COA})$ & $63(30.3)$ & $81(38.9)$ & $39(18.8)$ & $23(11.1)$ & $2(1.0)$ & 208 & \\
\hline Total & 82(28.6) & 103(35.9) & $55(19.2)$ & 41(14.3) & $6(2.1)$ & 287 & \\
\hline
\end{tabular}

$\chi^{2}=$ Chi square

Although, there are indications that there were lesser votes from the elderly who voted for the Coalition 2016, according to the sampled surveyed in this investigation. Among them were those within the age category of 41 to 61 years and above. These differences were statistically significant $X=0.022$ with a degree of freedom of 8.

\subsection{Respondents Social Media Platform Preference}

The table below shows that, the media preference of the electorates during the 2016 Presidential elections which shows Facebook as the mostly used social media platform of 147 (51.2 percent), followed by WhatsApp 60 (20.9 percent) with twitter being the lowest viewed platform of 11 (3.8 percent) (Table 6).

Table 6: Respondents Social Media Platform Preference

\begin{tabular}{lcc}
\hline Variable & Frequency $(\mathbf{n = 2 8 7})$ & Percent \\
\hline FACEBOOK & 147 & 51.2 \\
TWITTER & 11 & 3.8 \\
WHATSAPP & 60 & 20.9 \\
NEWSPAPER & 26 & 9.1 \\
RADIO & 21 & 7.3 \\
TELEVISION & 22 & 7.7 \\
\hline Total & $\mathbf{2 8 7}$ & $\mathbf{1 0 0 . 0}$ \\
\hline
\end{tabular}

\subsection{Socio-demographic Characteristics and Media}

As indicated in the table below, a cross tabulation showing gender against the media platform of the respondents media choices. The results herein shows the respondents preferred media platforms used in accessing information relating to politics during the 2016 electioneering season race. According to the findings, a sample of 287 respondents in the study about 51.2 percent (147) of respondents were heavily depended on social networking site of Facebook to harvest information for political communication. As a way of enriching their political knowledge about the various political parties and their leaders during the 2016 campaign season (Table 7). 
Table 7: Cross Tabulation Showing Gender Against the Media Platforms

\begin{tabular}{|c|c|c|c|c|}
\hline \multicolumn{3}{|c|}{ Gender } & \multirow[b]{2}{*}{ Total } & \multirow[b]{2}{*}{ Test statistics } \\
\hline Variables & Male ( percent) & Female ( percent) & & \\
\hline Facebook & $90(31.4)$ & 57 (19.9) & $147(51.2)$ & $\chi^{2}=0.307$ \\
\hline Twitter & $3(1.0)$ & $11(2.8)$ & $11(3.8)$ & \\
\hline WhatsApp & $34(11.8)$ & $26(9.1)$ & $60(20.9)$ & \\
\hline Newspaper & $17(5.9)$ & $9(3.1)$ & $26(9.1)$ & \\
\hline Radio & $12(4.2)$ & $9(3.1)$ & $21(7.3)$ & \\
\hline Television & $11(3.8)$ & $11(3.8)$ & $22(7.7)$ & \\
\hline Total & $167(58.2)$ & $120(41.8)$ & $287(100)$ & \\
\hline
\end{tabular}

$\chi^{2}=$ Chi square

Some 20. 9 percent which accounts for (60 respondents) the findings disclosed that were highly visible on social networking called WhatsApp. Furthermore, the results shows that about 9.1 percent (26 respondents) were also regular readers of Newspapers in order to abreast themselves with developments revolving around politics.

Also, 7.7 percent some 22 respondents indicates that they followed television programme during the campaign season. And further 7. 3 percent were keen listeners to radio in order to monitor information emanating from political parties and politicians respectively. The lowest scores on the media platform preference as the findings depicts is Twitter. Which accounts for 3.8 percent (11 respondents). These differences were not statistically significant $(\mathrm{p}=0.307)$.

Based on this findings, it is quite intriguing and convincingly apt to state that majority of participants in the research investigation used Facebook to generate information on politics or take part in conversations revolving around politics, civics among other enlightenments discuss. In greater scale is overwhelming to argue that social media users as the present investigation discloses built a faculty of discerning preference that onwards gave users the optimal chances to follow the aforesaid media platforms to enlighten themselves about Gambian political trajectory.

The present findings of the investigation has manifested that voter choices in passing decisions at polls was immensely influence by media platforms such as social media networking sites they followed to harvest political information. Among number of Gambian voters who took part in the research, justify that Facebook and WhatsApp were a dominant mediums employed as their space to accessed information. About 51.2 percent of the respondents did mentioned that social networking site specifically Facebook was their most followed outlet to accessed political communication from the campaigns happening in the offline space. Certain literature has shown that social media cultivate political awareness of its users (Geoff et al., 2012; Gil de Zunigal et al., 2014).

Prior findings has lamented that presidential elections campaigns has made profound increased in terms of using online space. This is believes to have yielded substantial degree when it comes to civic participation and drawing the ordinary voter attention to turn to the polls.

Previous search by scholars also demonstrates that Facebook has the potent as a social networking medium to attract considerable number of people to go to polls. Based on the relevant information people come across from politicians and their parties. For example, during the U.S 2010 Congressional Election which manifested a positive impact of online get-out-the-vote message and further translated into actual voting behaviours of voters (Bakshy, Bond, Eckles and Jones, 2017).

The present investigation respondents who constituted the voting populace in this sampled study confirmed that it is of great relevance for politicians or political party presence on media platforms such as social media outlets. As a way of sharing political messages with would-be party supporters.

Scholars who has done extensive search on the association between social media networks and its increasing usage for electoral processes for voter attraction. It is asserted that social media is instrumental in changing the political mindsets of its users. In light of this, politically, social media shapes attitudes of people both social and political dimensions. 3As similar study on influence of social media technologies on contemporary Russian society has shown (Baluev and Kaminchenko, 2015). This assertion is greatly confirmed by this results. In the sense that, the scale of magnitude at which social media infrastructure accommodates ordinary people involvement and conversation relating to political discuss and civics is overwhelming. Again, this in closer relation to The Gambia's experience as of December 2016 presidential election is a significant talking point for change of governance. 
It is quite appealing to discover that social media influence has potentially meaningful effects. For the reason that it serves as a source of force in convincing friends who received the shared manufactured political craft messages to go the polls. More crucially, this current investigation findings to a great extend corroborates certain previous studies. Further, the results presented establishes the increasing evidence relating to social networks. That is to vehemently state that social networks immensely can be instrumental tool in shaping offline behaviour. More so, when it concerns about social and political life. As often argue by Manuel Castells (2005) that political opinion and political behaviours are greatly shape in what he refer to through 'communication space'. Which includes the social networking sites.

Democratisation of information was partly aided by social media in The Gambian political landscape trend. Contextually, initial studies demonstrates that social media is one of the most significant source of information that enlighten voters about political party role and thus, it helps the voter populace to pass a decision whether to vote or not to vote (Sharma and Parma, 2016; Mustapha et al., 2017).

It is without no doubt that providing credible information for audience through social networks such as Facebook, WhatsApp amongst others would greatly become a reliable source for electorates to glue to. Specifically, at an era when the mainstream media faced with strife challenges of exercising independence as its cardinal tenet of its trade (journalism). As the prime example of The Gambia for the past couple of years.

Some research findings has informed that when electorates regularly interact through the social media habitually they are likely to be involved in politics. Another finding also confirmed that people who get informed through social media platforms tend to participate more and in fact their participation leads to a robust information-seeking behaviours (Gil de Zuniga, Molyneux and Zheng, 2014). This was confirmed in this findings as majority of the respondents about 73.2 percent of voters said they voted because they were more interested in effecting political leadership change. What is more fascinating about the category of these respondents in the present findings is that they falls within 18 to 32 years old. Which can be consider to be youthful.

Based on the above discussed findings. In the examination towards providing some answers as to whether social media has influence Gambian voters in the 2016 presidential election. The findings sought to answer the following research questions.

RQ1: What were the attitudes and belief of Gambian youth concerning the use of social media in raising political consciousness?

The results of the findings has demonstrate that Gambian voters, particularly the young people who constituted roughly 63 percent of the population meaningfully used social media. As a result of this, one can state that it impacted on their political awareness and participation during the last presidential election. The findings shows that majority of the respondents in the research who casted their vote's majority among them were between the ages of 18 to 32 years old.

RQ2: What influence, if any, does social media have on voter behaviour and choices in The Gambia's 2016 election?

The study found that there some significant attribution to social media which was greatly utilised during political campaigning to reach out to potential voters. This investigation has shown that 51.2 percent of the respondents were using social networking sites of Facebook and 20.9 percent did used WhatsApp medium to generate information emanating political campaign ground offline. This confirms that in one way or the other as indicated by these findings social media has helped in changing the political narratives of The Gambia.

\section{CONCLUSION}

It would be undisputable to recognised the new energy dimension that social media has accompanied with. Essence to this, is that over the years it continues to create forum for more political debates, diverse forms of civil participation and socialisation. All these in one way or the other serves as innovation initiation incorporated in our daily political discourse. Which meaningfully intends to alert in some way the traditional political socialisation limited to the offline space. And in turns set the pace for new trajectory in impacting electoral processes and voter political consciousness to a new level. As postulates by Gil de Zunige et al., (2014), establishes that there are some significant relations about social media consumption of news and social interactions contribute to individual political engagement in the offline space.

Taking this closer to the African continent, for instance, the past decade particularly has witness a massive explosive rate of internet, mobile phones and of recent daily sophistication embedded in social media networking sites. To this end, it would hold some water to assay that social media impact is surfacing greatly in the quest towards changing the political narrative of many societies. More so, nascent democracies in Sub-Saharan nations like The Gambia significantly getting the taste of social media use in enabling political expression and political participation to flourish. Social media continues to serves as an alternative channel for information generation, especially in situation where tradition media struggles with cancer of censorship implanted by dictatorship (Schreiner, 2015). 
Based on findings revelation, social media is becoming the alternative for ordinary citizens. That is to say that social media space incredibly serving as a supplementary linkage for a more proactive way of political expression. Moreover, one thing is certain is that it usage in political conversations proper is the pathway for a politically active future, especially among the young people of The Gambia and elsewhere.

McCombs and Shaw (1993), in their agenda-setting and media framing suggests that the media has not only become a successful tool that dictates what the public see and hear, but in fact, set the pace on how to think about it and significantly what to think. In light of this, with the advent of media outlets such as social media serving as marketplace of ideas in our political conversation trend. In dealing with electorates, the honours lies on the political players to incorporate this medium into their political communication approach to beseech better mass political awakening.

This present study confirmed the hypothesis of the thesis which indicated that young people are among the majority who voted for the "Coalition 2016".

In the final analysis, we could state that this claim is highly supported by the present findings.

\subsection{Limitations}

In the journey towards the examination of this very findings, which intends to examine whether social media has any influence on the mindsets of Gambian voters in the 2016 election. It worth to note that there are certain limitations that truly necessitated some merits of attention.

Chiefly, this study was wholly limited to certain selected regions of The Gambia namely, Banjul (capital city), Kanifing Municipal Council and West Coast Region. Simply, these settlements are located in the urban centres where internet connectivity is far better than other regions of the country. In essence, the findings above doesn't permit the generalisation based on the study population. In this way, it could be further expanded by future research in a bid to use generalise scale of the findings establish therein.

Additionally, the gender dimension of male ratio compared to the female respondents on the study. Statistically was dominated mainly by male respondents. That established some scale of imbalance in terms of gender in the investigation. At least in the way, future investigation could help to balance the equation of respondents so-as-to give it some gender fairness. That is equal proportion of male and female would-be respondents can be targeted by future study.

Also, when it comes to the methodology employed for data collection the present research did used questionnaire to collect primary data from voters. To some extent, this could be limited, especially in light of the closed-ended questions which were used in the questionnaire format. In this regard, future research would endeavour to incorporate mixed data collection techniques such as focus groups, interviews, questionnaire and survey for wider generation of information from respondents in the study.

\subsection{Suggestions for Future Research}

Further, future research would do great help to establish some connection about voter political consciousness in future elections and information interaction from social media platforms. Does it enhance political voices in offline space and meaningful participation?

Based on the present findings, on the respondents motivation for voting behaviour in the December 2016 presidential election. Greater majority of the respondents about 73.2 percent indicates that they voted because they wanted political leadership change. Ideally, one can say that there are numerous factors associated with this. Based on the previous political situation of The Gambia where people political rights and freedoms were none existence. Mass incarceration of political rivals and journalists was not a secret affair. In order to reach this important search for some answers, a survey approach with incorporation of mixed method of data collection would be beneficial. As a way of establishing contextually the relationship of the aforesaid research suggested area. Significantly, this could aims to target the whole country at large as a way of enabling the general context of Gambians ultilisation of social media in their political life. To be more examine to give some deeper sense.

\section{Acknowledgement}

I wish to acknowledge an enormous debt to many people for their immense encouragement and support in carrying out this work. I candidly appreciate the support provided at all times: ranging from data collection phase to writing. Interesting it's!

This academic undertaken would have not be possible without the essential couching and guidance of my able supervisor, Prof. Dr. Gamze Yücesan Özdemir. I regard her as a best supervisor that a graduate student dream about. Her suggestions, ideas, and critique at various stages of this research went splendid!

\section{Author's Profile}

Mr. Yaya B. Baldeh is a Gambian journalist, academic and researcher. Mr. Baldeh holds a Master's Degree in Journalism from Ankara University, Graduate School of Social Sciences, Department of Journalism, Turkey. 
Previously, he bagged a bachelor degree in Development Studies and English Language from The University of The Gambia and Advanced Diploma in Journalism from The Gambia Press Union School of Journalism.

His research interest is Journalism Studies, Global Media, Social Media Networks and Democracy, etc.

\section{References}

Ahmad, R., Olanrewaja, T. (2017). The Role of Social Media during the 2015 Voting Process in the Nigeria Election. Research Journal of Applied Sciences, 12(2): 281-287. http://docsdrive.com/pdfs/medwelljournals/rjasci/2017/281-287.pdf

Almqvist, M., F., (2016). Piracy and the Politics of Social Media. Social Sciences, Linkoping University, Sweden.

Alotaibi, N. (2013). Media Effects on Voting Behavior. European Scientific Journal. https://eujournal.org/index.php/esj/article/view/1557

Adeola, R., (2017). What the rest of Africa can learn from The Gambia's transition to democracy. The Conversation. https://theconversation.com/what-the-rest-of-africa-can-learn-from-the-gambias-transition-todemocracy-71822

ARTICLE 19. (2013). The Gambia: New internet law furthers government crackdown on free expression. https://www.article19.org/resources.php/resource/37152/en/the-gambia:--new-internet-law-furthersgovernment-crackdown-on-free-expression

Baluev, D., and Kaminchenko, D., I., (2015). Study of the Impact of Social Media Technologies on Political Consciousness: Specifics of Russian Approaches. Canadian Centre of Science and Education.

Baluev, D. (2013). Political Role of Social Media as a Field of Research and as a Field of University Level Study. Journal of Social \& Development Sciences, 11, 488-493.

Barret, P., and Cameron, M. (2014). Can Social Media Predict Election Results? Evidence from New Zealand. Journal of Political Marketing, 416-432. http://www.tandfonline.com/doi/abs/10.1080/15377857.2014.959690

Bimber, B., and Davis, R. (2003). Campaigning Online the Internet in U.S. Elections. Oxford University Press.

Bode, L., Borah, P., Vraga, E., and Shah, D. (2014). A New Space for Political Behavior: Political Social Networking and its Democratic Consequences. Journal of Computer-Mediated Communication, 414-429.

Boulianne, S. (2015). Social Media Use and Participation: A Meta-analysis of Current Research, Information, Communication \& Society. http://www.tandfonline.com/doi/full/10.1080/1369118X.2015.1008542

Boyle, M., and Schmierbach, M. (2009). Media Use and Protest: The Role of Mainstream and Alternative Media Use in Predicting Traditional and Protest Participation. Communication Quarterly, 57:1, 1-17. http://www.tandfonline.com/doi/abs/10.1080/01463370802662424

Bright, J., Ganesh, B., Hale, S., and Howard, P. (2017). Does Campaigning on Social Media Make a Difference? Evidence from candidate use of Twitter during the 2015 and 2017 UK Election. https://arxiv.org/ftp/arxiv/papers/1710/1710.07087.pdf

Cammaerts, B. (2015). Social Media and Activism. Oxford, UK: Wiley-Blackwell.

Castells, M. (2015). Networks of Outrage and Hope: Social Movements in the Internet Age. Polity Press.

Castells, M., and Cardoso, G. (2005). The Network Society: From Knowledge to Policy. Washington, DC: Johns Hopkins Centre for Transatlantic Relations.

Cakar, S., Gucdemir, Y., and Erturk, D. (2015). Political Preferences of generation Y University Students with regards to Governance and Social Media: A Study on March 2014 Local Elections. Procedia-Social \& Behavioral Sciences, 174, 791-797. https://www.sciencedirect.com/science/article/pii/S1877042815006679

Chidi, A.M., Chimee, N. (2016). Social media and political change in the $21^{\text {st }}$ Century: The African Experience. Glocalism: Journal of Culture, Politics and Innovation. http://www.glocalismjournal.net/issues/networksand-new-media/articles/social-media-and-political-change-in-the-21st-century-the-african-experience.kl

Davies, R. (2014). Social Media in Election Campaigning. European Parliamentary Research Service.http://www.europarl.europa.eu/RegData/bibliotheque/briefing/2014/140709/LDM_BRI(2014)1407 09 REV1 EN.pdf

Dimitrova, D., and Bystrom, D. (2013). The Effects of Social Media on Political Participation and Candidate Image Evaluations in the 2012 Iowa Caucuses. SAGE: 56(1), 1568-1583. http://journals.sagepub.com/doi/pdf/10.1177/0002764213489011

Dutta, N., Bhat, K., A. (2017). Use of Social Media for Political Engagement: A Literature Review. Research Gate. https://www.researchgate.net/publication/312468953

Enli, G., Moe, H., (2013). Introduction to Special Issues: Social Media and Election Campaigns- Key Tendencies and Ways Forward. Information, Communication \& Society, 16(5), 637-645. http://www.academia.edu/5028153/Introduction_to_Special_Issue_Social_Media_and_Election_Campaign s_Key_Tendencies_and_Ways_Forward

Entona, C., and Licudine, V. (2013). Social Media and the 2013 Philippine Senatorial Elections. Korad- 
Adenauer Stiftung.

Farnen, R., German, D., Dekker, H., and Sunker, H. (2014). E-political Socialisation, the Press and Politics: the Media and Government in the USA, Europe and China. International Academic, Frankfurt.

Gambia Bureau of Statistics (2013). Access to Information and Communications Technology, 2013 Population and Housing Census. http://www.gbos.gov.gm/2013.php

Gambia Bureau of Statistics (2013). The Gambia 2013 Population and Housing Census Preliminary Results. Banjul, The Gambia.

Gibson, R., Rommele, A., and Ward, S. (2004). Electronic democracy: mobilisation, organisation and participation via new ICTs. Routledge.

Gil de Zunigal, H., Molyneux, L., and Zheng, P. (2014). Social Media, Political Expression, and Political Participation: Panel Analysis of Lagged and Concurrent Relationship. Journal of Communication (64), 612634. http://onlinelibrary.wiley.com/doi/10.1111/jcom.12103

Gumede, W. (2016). Social Media Keep Africa in Check. African Independent. https://www.africanindy.com/opinion/social-media-keep-africa-in-check-5564193

Howard, P.N. (2011). The Digital Origins of Dictatorship and Democracy: information Technology and Political Islam. Oxford University Press.

Hand, M., Sandywell, B. (2002). E-Topia as Cosmospolis or Citadel on the Democratising and DeDemocratising Logics of the Internet, or, toward a Critique of the New Technological Fetishism. SAGE Journals pp. 197-225.

Ito, Mizuke et al. (2008). Civic Life Online: Learning how Digital Media Can Engage Youth. Cambridge, MA: The MIT Press.

Iwata, T. (2015). Social media practices during the political change in Sub-Saharan Africa. Ritsumeikan Annual Review of International Studies, Vol.4, pp.47-72. http://www.ritsumei.ac.jp/acd/cg/ir/college/bulletin/evol.14/vol.14_03_Iwata.pdf

Jobe, A. (2017). Social Media Gave Birth to Democratisation-The Gambia Experience. The Point Newspaper, Gambia. http://thepoint.gm/africa/gambia/article/social-media-gave-birth-to-democratisation-the-gambiaexperience

Kalyango, Y., Adu-kumi, B. (2013). Impact of Social Media on Political Mobilisation in East and West Africa. Global Media Journal. http://www.globalmediajournal.com/open-access/impact-of-social-media-onpolitical-mobilization-in-east-and-west-africa.php?aid=35907

Kamp, M., et al. (2016). Assessing the Impact of Social Media: on Political Communication and Civic Engagement in Uganda. Konrad Adenauer Stiftung.

Kidd, D., McIntosh, K. (2016). Social Media and Social Movements. John Wiley \& Sons Ltd.

Lim, M., (2013). Many Clicks but Little Sticks: Social Media Activism in Indonesia. Journal of Contemporary Asia 43:4, 636-657. http://www.tandfonline.com/doi/pdf/10.1080/00472336.2013.769386

Loader, B.D. \& Mercea, D. (2011). Networking democracy? Social media innovations in participatory politics. Information Communication \& Society, 14(6), pp. 757-769.

Mabweazara, H.M. (2015). Mainstreaming African digital cultures, practices and emerging forms of citizen engagement. $\quad$ African $\quad$ Journalism $\quad$ Studies, $36: 4,11$. http://www.tandfonline.com/doi/pdf/10.1080/23743670.2015.1119486

Mahmud, A., and Amin, R. (2017). Use of Social Networking Media in Political Participation: A Study on Dhaka University Students. Sociology \& Anthropology, 5, 481-488. http://www.hrpub.org/journals/article_info.php?aid=6007

McCombs, M., and Shaw, D. (1993). The Evolution of Agenda-Setting Research: Twenty-Five Years in the Marketplace of Ideas. Journal of Communication 43(2).

Meti, V., Khandoba, P.K., \& Guru, M.C. (2015). Social Media for Political Mobilisation in India: A Study. Journal of Mass Communication \& Journalism, 5: 275. https:/www.omicsonline.org/open-access/socialmedia-for-political-mobilization-in-india-a-study-2165-7912-1000275.

Mngusuul, U. (2015). Social Media and the Mobilisation of Youths for Socio-Political Participation. New Media and Mass Communication, http://www.iiste.org/Journals/index.php/NMMC/article/view/26610/27259

Mosharafa, E. (2012). Can Social Media Incite Political Mobilisation? Journal of Mass Communication Research of Alazhar University, 38 pp.701-717. http://www.academia.edu/10752591/Can_Social_Media_Incite_Political_Mobilization

Mutanana, N. (2016). Social Media and Political Mobilisation: An Analysis of the July 2016 Zimbabwe Shut Down. American Journal of Trade and Policy. http://journals.abc.us.org/index.php/ajtp/article

Mutsvairo, B., Kamau, S. and Chibita, M. (2016). Digital Activism in the Social Media Era: Critical Reflections on Emerging Trends in Sub-Saharan Africa. Palgrave MacMillan.

Paterson, C. (2013). Journalism and Social Media in the African context. Ecquid Novi: African Journalism 
Studies, 34:1, http://www.tandfonline.com/doi/pdf/10.1080/02560054.2013.767418

Patti, D., Polyak, L., \& D’Antonio, S. (2017). Interactive Cities: Digital, Social Media and User-generated Content Improving Urban Governance. URBACT Interactive Cities. http://urbact.eu/sites/default/files/interactive_cities_baseline_0.pdf

Perfect, D. (2008). Politics and Society in The Gambia Since Independence. History Compass 6(2): 426-438, Blackwell Publishing Ltd.

Sallah, T.M. (1990). Economics and Politics in The Gambia. The Journal of Modern African Studies 28(4) pp. 621-648

Shah, D., Vraga, E., Veenstra, A., \& Gil de Zuniga, H. (2010). Digital Democracy: Reimagining Pathways to Political Participation. Journal of Information Technology \& Politics 7(36-51). http://www.tandfonline.com/doi/pdf/10.1080/19331680903316742?needAccess=true

Soeung, S. (2013). Social Media's Growing Influence on Cambodian Politics. Asia Pacific Bulletin. https://www.eastwestcenter.org/sites/default/files/private/apb_222.pdf

Stromer-Galley, J. (2014). Presidential Campaigning in the Internet Age. Oxford University Press.

Theocharis, Y., and Gercia-Albacete, G. (2012). Social Media and Political Mobilisation: A Comparison of the Occupation Movements in Spain, Greece and the US. http://paperroom.ipsa.org/papers/paper_13718.pdf

Windeck, F. (2010). Political Communication in Sub-Saharan Africa and the Role of New Media. http://www.kas.de/wf/doc/kas_19703-544-2-30.pdf?100526130209 